\title{
QUALITATIVE AND QUANTITATIVE ANALYSIS OF THE HOUSING STOCK IN UKRAINE
}

\section{Nikolaiev V. P.}

\section{INTRODUCTION}

The state housing policy of the independent Ukraine, similarly to the one of the former USSR, has always envisaged the state's participation in the provision of housing to citizens. The right to housing and the state's role in the provision of housing to citizens are defined in Article 47 of the 1996 Constitution of Ukraine, which declares that the state creates the conditions under which each citizen shall be able to build their own housing, purchase it or lease it. Vulnerable citizens requiring social protection receive housing from the state and local self-government authorities free of charge or at affordable prices in accordance with the law ${ }^{1}$.

The modern policy of applying private property law to housing displays, as we believe, contradictions between the short-term attractive goals and the long-term negative ramifications of the implementation of the provisions of the current Constitution. While the provision of the population with housing in the process of the almost free-of-charge privatization in the 1990s looked like the state's "gift" for flat dwellers, the prospect of renovating old flats and purchasing new housing at one's own expense and paying the entire cost of the housing and utilities services, especially following the multiple tariff raising in 2015, came to be viewed as an excessive burden for many households. At the same time, most of the inevitable costs for further purchase, maintenance and repair of houses have not yet been recognized by the population, as the respective component was lacking in tariffs and statistics. Provided it is taken into account, the home ownership provided for by the Constitution becomes inaccessible for most of the population.

A need arises to develop new strategies in the housing sphere due to the necessity to properly maintain houses, renovate housing stock and guarantee the sustainable provision of housing to the population.

In Ukrainian scientific literature, the modern policy and state strategies in the housing sphere were studied in the monographs and doctoral theses in various specialties: by V. Bozhanova, 20072, D. Levchynskyi, 2012 ${ }^{3}$,

\footnotetext{
${ }^{1}$ Constitution of Ukraine. // URL: http://www.president.gov.ua/documents/constitution

${ }^{2} \mathrm{~V}$.Yu. Bozhanova. Business mechanism of increasing housing availability for population. Dnepropetrovsk. Science and Education, 2007. - 392 p. (in Ukrainian)
} 
I. Lysov, 2012 , Yu. Mantsevych, 2007 ${ }^{5}$, O. Nepomniashchii, 20136, N. Oliinyk, $2011^{7}$, V. Omelchuk, $2012^{8}$, K.Palyvoda, $2010^{9}$, as well as in other authors' works.

The above-mentioned authors mostly focused on the organizational and financial issues of providing a wider availability of housing, development of housing construction, and search of state mechanisms to provide solutions thereto. In spite of the value of the financing schemes improvements, ways to reduce housing prices and provide relief to certain population categories proposed by them, the problem of the possibility to satisfy the housing needs of all citizens on the basis of constitutional provisions, the Laws of Ukraine and applicable state policy papers has never been raised and remains unsolved.

Special attention should be paid to the monograph by V. Kravchenko, K. Palyvoda, V. Poliachenko ${ }^{10}$, in which the main problem inherent to the housing sphere is specified as the contradiction between the need in housing as prime necessity and the shortage or lack of the possibilities of satisfaction thereof either by an individual or by a social group or even society as a whole which requires the state to assume an active role, various in its mechanisms [10, P. 137]. New views on the problem of housing provision to citizens of Ukraine are found in the publications by T. Nikolaieva ${ }^{11}$,

${ }^{3}$ D.L. Levchynskyi. Government regulation of the investment process of housing stock reconstruction : synopsis of a thesis for the degree of Doctor of Sciences in Economics : 08.00.03, Zaporizhzhia, Classical Private University. 2012. 40 p. (in Ukrainian)

${ }^{4}$ I.V. Lysov. State housing policy of Ukraine and its regions: theory, methodology, practice [Text] : monograph / I.V. Lysov, Academy of Municipal Administration - Donetsk : IuhoVostok Publishing House, 2012. - 399 p. (in Ukrainian)

${ }^{5}$ Yu.M. Mantsevych. Social and economic issues of the development of housing services in Ukraine and the strategy of its improvement: [monograph]. Kyiv. Profi-Inform Publishing House. 2007. - 388 p. (in Ukrainian)

${ }^{6}$ O.M. Nepomniashchii. Methodological framework for forming and implementing state housing policy : synopsis of a thesis for the degree of Doctor of Sciences in State Administration : 25.00.02. Donetsk. Donetsk State University of Management. 2013. - 36 p. (in Ukrainian)

${ }^{7}$ N.I. Oliinyk, State regulation of the housing market in Ukraine. Thesis for the degree of Doctor of Sciences in State Administration, 25.00.02. Kyiv, National Academy of State Administration. 2011. - 391 p. (in Ukrainian)

${ }^{8}$ V.A. Omelchuk. State regulation of the affordable housing market in Ukraine. Thesis for the degree of Doctor of Sciences in Economics 08.00.03. - Economics and National Economy Management. Kyiv. Scientific and Research Institute of Economy. 2012. - 422 p. (in Ukrainian)

${ }^{9}$ K.V. Palyvoda. Monetary resources and financial mechanisms of capital investment into housing construction : synopsis of a thesis for the degree of Doctor of Sciences in Economics : 08.00.08. Kyiv. No publishing house. 2010. - 38 p. (in Ukrainian)

10 V.A. Kravchenko, K.V. Palyvoda V.A. Poliachenko. Fundamentals of housing economics. Kyiv. Osnova. 2007. - P. 416 (in Ukrainian)

${ }^{11}$ T.V. Nikolaieva. Financial and economic mechanism of maintaining and reconstructing housing stock in the context of ownership relations transformation. Scientific bulletin of the National University of the State Tax Office of Ukraine (Economy, Law). / Science editor P.V. Melnik. Kyiv, National University of the State Tax Office of Ukraine. 2012. No. 1 (56). P. $81-85$ (in Ukrainian) 
P. Panteleiev ${ }^{12}$, A. Shcherbyna ${ }^{13}$, where, in contrast to other authors' publications, its connection with the ownership of housing, the necessity to concentrate residential property with the most efficient owners is indicated.

This entails the necessity to study a great number of related issues: the state of the houses and evaluation of the accumulated and subsequent regular needs in capital repairs, full cost of the effective house ownership, definition of the real standards of housing provision, research of citizens' opinion of the necessary reforms. This article's task is to systematize the quantitative and qualitative approaches to the issue of housing stock preservation and sustainable provision of population with housing.

\section{Housing construction and housing provision: quantitative evaluation}

After Ukraine shifted to the liberal state model and the use of market regulation mechanisms, the volumes of housing construction started to be defined no so much by the government's social (housing) policy as by the demographic processes, urbanization and consumer demand, with a restricted use of, as it transpired later, imperfect funding and financing mechanisms. The share of the state and local budgets in the yearly spending on housing construction was declining and is currently less than $1 \%$ (table 1 ).

Table 1

Housing construction in Ukraine since independence

\begin{tabular}{|c|c|c|c|c|c|c|c|}
\hline Years & $\begin{array}{c}\text { Housing } \\
\text { commissioned, } \\
\text { million } \mathbf{~ m}^{\mathbf{2}}\end{array}$ & Years & $\begin{array}{c}\text { Housing } \\
\text { commissioned, } \\
\text { million } \mathbf{~ m}^{\mathbf{2}}\end{array}$ & $\begin{array}{c}\text { Share of } \\
\text { state } \\
\text { funding }\end{array}$ & Years & $\begin{array}{c}\text { Housing } \\
\text { commissioned, } \\
\text { million } \mathbf{~ m}^{\mathbf{2}}\end{array}$ & $\begin{array}{c}\text { Share of } \\
\text { state } \\
\text { funding }\end{array}$ \\
\hline 1992 & 14,1 & 2000 & 5,6 & 1,5 & 2009 & 6,4 & 1,7 \\
\hline 1993 & 12,3 & 2001 & 5,9 & 1,9 & 2010 & 5,0 & 0,3 \\
\hline 1994 & 10,1 & 2002 & 6,1 & 2,2 & 2011 & 7,2 & 0,8 \\
\hline 1995 & 8,7 & 2003 & 6,4 & 4,3 & 2012 & 10,8 & 0,7 \\
\hline 1996 & 6,8 & 2004 & 7,6 & 2,5 & 2013 & 11,2 & 0,5 \\
\hline 1997 & 6,4 & 2005 & 7,8 & 3,6 & 2014 & 9,7 & 0,3 \\
\hline 1998 & 5,8 & 2006 & 8,6 & 2,8 & 2015 & 11,0 & 0,5 \\
\hline 1999 & 6,1 & 2007 & 10,2 & 1,6 & 2016 & 9,4 & 0,3 \\
\hline
\end{tabular}

${ }^{1}$ Since 2014, the temporarily occupied territory of the Autonomous Republic of Crimea, Sevastopol and the antiterrorist operation zone are excluded. As this complicates the further analysis in absolute numbers, further we will have to use the data obtained before 2014 in respective comparisons.

Source: State Statistics Service of Ukraine

${ }^{12}$ P.O. Panteleiev. Investment process of maintaining residential houses. Forming market relations in Ukraine. 2013. No. 11 - P. 108-112 (in Ukrainian)

${ }^{13}$ V.P. Nikolaiev, A.A. Shcherbina. A model of development of a residential property and housing and utilities services market in view of consumers' payment capacities. Construction operations : cross-sectoral scientific and technical collection of works. Kyiv. Research Institute of Building Production. 2017. No. 63/3 - P. 34-41 (in Ukrainian) 
Comparing the indicators of commissioning areas per 1000 individuals in Ukraine and in other post-Soviet republics, Ukraine's lagging behind was and is now obvious (fig. 1). It is largely attributable to the low level of the state's involvement in the direct financing of housing construction or in the support of affordable housing programs (in 2017-2018: Belarus - 25.2\%, Russia $-5.4 \%$, Kazakhstan $-17 \%$ ). In Ukraine, 30.3 thousand $\mathrm{m}^{2}$ of the total area of housing was accepted into service at the state budget costs in 2016 ( $0.3 \%$ of the total amount), which is $42.3 \%$ less than in 2015 . Given these newly built flats have an average area, this will suffice only for 365 families.



\section{Fig. 1. Commissioning of housing in Ukraine and some CIS countries}

Source: plotted by the author based on the government statistics of respective countries

It is believed that the normal demand for housing in a country can be supported when the average monthly salary reaches the level of the price of $1 \mathrm{~m}^{2}$ of housing. As per the State Statistics Service of Ukraine, the average monthly salary as of the beginning of 2019 amounted to UAH 8,865, while the price of one square meter of housing in the capital was UAH 25,000, and in the regions, it was UAH 10,000 to 20,000 , i.e., several times lower. Ukraine holds one of the lowest places in the world as per the housing affordability index (depending on the information sources).

Thus, the decrease of the state financing lead to the shrinking of the volumes of housing construction two to three times compared to the end of the 80s. Altogether, since independence and until the beginning of 2019, nearly 0.23 billion $\mathrm{m}^{2}$ of new and renovated housing has been commissioned.

The cost of housing construction in the conditions of underdeveloped and non-transparent market relations is representative for the analysis of the falling demand for new housing, as the excessive price of housing also limits this demand (table 2). 
The 2018 statistics show that from UAH 53,247 million of capital investments in housing, UAH 29,345 million, or $55 \%$, were spent on construction, and 8.7 million $\mathrm{m}^{2}$ of housing were commissioned. This means that $1 \mathrm{~m}^{2}$ cost investors UAH 6,120, and construction companies - UAH 3,373 . At the same time, the housing prices were and still are substantially higher, which had to signify a high profitability of housing construction. However, strange as it may seem, according to the official statistics, during all years of independence, building enterprises have been lossmaking, in particular, since 2010 (fig. 2).

Table 2

Cost indicators of housing construction

\begin{tabular}{|c|c|c|c|c|}
\hline Years & $\begin{array}{c}\text { Capital } \\
\text { investments in } \\
\text { housing } \\
\text { constructions, } \\
\text { UAH million }\end{array}$ & $\begin{array}{c}\text { Volume of } \\
\text { performed } \\
\text { construction } \\
\text { works, UAH } \\
\text { million }\end{array}$ & $\begin{array}{c}\text { Total housing } \\
\text { commissioned, } \\
\text { million } \mathbf{~ m}^{\mathbf{2}}\end{array}$ & $\begin{array}{c}\text { New housing } \\
\text { commissioned, } \\
\text { million } \mathbf{~ m}^{2}\end{array}$ \\
\hline 2010 & 25,754 & 6,876 & 8.6 & 8.1 \\
\hline 2014 & 33,177 & 11,292 & 9.7 & 8.8 \\
\hline 2015 & 45,610 & 13,908 & 11.0 & 9.8 \\
\hline 2016 & 42,503 & 18,012 & 9.4 & 8.3 \\
\hline 2017 & 53,372 & 23,730 & 10.2 & 10.2 \\
\hline 2018 & 53,247 & 29,345 & 8.7 & 8.7 \\
\hline
\end{tabular}

Source: State Statistics Service of Ukraine

Thus, the economic mechanism regulation in the housing construction sector could somewhat change the situation on the residential property market.

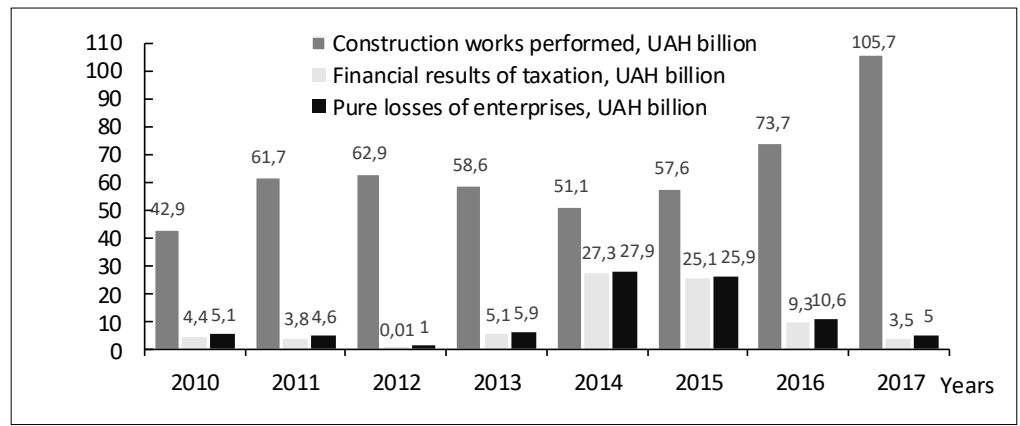

Fig. 2. Losses of housebuilding

Source: State Statistics Service of Ukraine 
As a result of the housing construction rates described above, as of 1 January 2018, the total area of housing stock amounted to 984.8 million $\mathrm{m}^{2}$. Almost entire housing stock $(98.4 \%)$ was concentrated in multi-apartment buildings and single-family houses, the remaining 16.2 million $\mathrm{m}^{2}(1.6 \%)$ - in company dormitories (fig. 3).

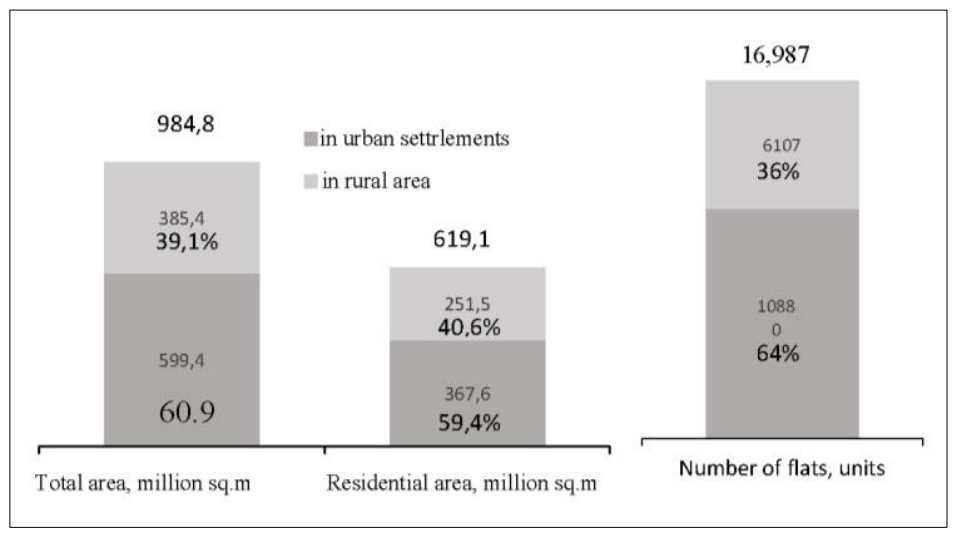

Fig. 3. Housing stock in Ukraine

Source: State Statistics Service of Ukraine

Despite the significant decline in the housing construction, the average availability of housing grew due to the falling population size (fig. 4).

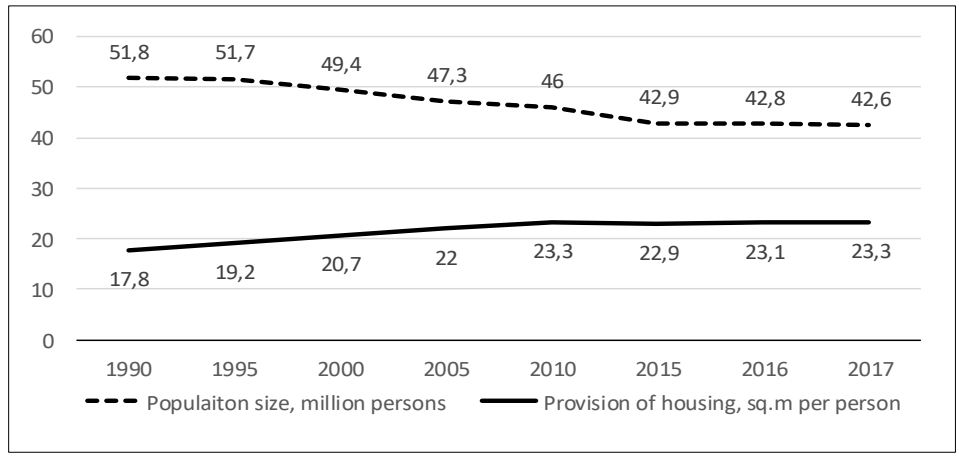

Fig. 4. Population size and provision of housing

Source: State Statistics Service of Ukraine 
Currently, 0.4 flat is available per person. At the same time, there is a waiting list for housing, which has virtually not moved and no data on which has been available since 2015 (table 3). However, the structure of housing stock (the number of residential houses) as per construction year is very disadvantageous in terms of its quality, as its maintenance is very onerous for its dwellers (tables 4, 5).

Table 3

Provision of housing to citizens

\begin{tabular}{|c|c|c|c|c|c|}
\hline \multirow[b]{2}{*}{ Years } & \multicolumn{3}{|c|}{ Flats } & \multirow{2}{*}{$\begin{array}{l}\text { Number of } \\
\text { families on } \\
\text { the housing } \\
\text { waiting list, } \\
\text { thousand }\end{array}$} & \multirow{2}{*}{$\begin{array}{l}\text { Number of } \\
\text { families } \\
\text { provided with } \\
\text { housing, } \\
\text { thousand }\end{array}$} \\
\hline & $\begin{array}{l}\text { Total area, } \\
\text { million } \mathbf{m}^{2}\end{array}$ & $\begin{array}{l}\text { Number, } \\
\text { thousand }\end{array}$ & $\begin{array}{c}\text { Per one } \\
\text { dweller, } \\
\text { unit }\end{array}$ & & \\
\hline 1990 & 922.1 & 17,656 & 0.34 & 2,638 & 235 \\
\hline 1995 & 978.3 & 18,303 & 0.35 & 2,411 & 82 \\
\hline 2000 & $1,015.0$ & 18,921 & 0.38 & 1,765 & 32 \\
\hline 2005 & $1,046.4$ & 19,132 & 0.40 & 1,323 & 20 \\
\hline 2010 & $1,079.5$ & 19,322 & 0.42 & 1,139 & 11 \\
\hline 2015 & 973.8 & 16,886 & 0.39 & - & - \\
\hline 2016 & 977.9 & 16,912 & 0.40 & - & - \\
\hline 2017 & 984.8 & 16,987 & 0.40 & - & - \\
\hline
\end{tabular}

Source: calculated by the author based on the data of the State Statistics Service of Ukraine

Table 4

Distribution of houses by the years of their construction

(as of the beginning of 2011)

\begin{tabular}{|c|c|c|c|c|}
\hline \multirow{2}{*}{ Years } & \multicolumn{2}{|c|}{ Total } & \multirow{2}{*}{ Cities } & \multirow{2}{*}{ Villages } \\
\cline { 2 - 3 } & Units & \% & & \\
\cline { 2 - 3 } & $\mathbf{1 0 , 1 5 9 , 6 3 6}$ & $\mathbf{1 0 0}$ & $\mathbf{4 , 0 5 5 , 3 9 4}$ & $\mathbf{6 , 1 0 4 , 2 4 2}$ \\
\hline before 1919 & 469,326 & 4.6 & 264,879 & 204,447 \\
\hline $1919-1945$ & $1,197,867$ & 11.8 & 441,633 & 756,234 \\
\hline $1946-1960$ & $2,552,198$ & 25.1 & 969,947 & $1,582,251$ \\
\hline $1961-1970$ & $2,445,067$ & 24.1 & 902,251 & $1,542,816$ \\
\hline $1971-1980$ & $1,645,922$ & 16.2 & 625,800 & $1,020,122$ \\
\hline $1981-1990$ & $1,092,574$ & 10.8 & 465,846 & 626,728 \\
\hline since 1991 & 756,682 & 7.4 & 385,038 & 371,644 \\
\hline
\end{tabular}

Source: $:^{14}$ (recent published data).

${ }^{14}$ Housing stock of Ukraine in 2010. State Statistics Service of Ukraine. Kyiv. 2011. 376 p. (in Ukrainian) 
In 2012, the number of houses reached 10150252, in $2013-10169123$, in 2014 - 10147185, and in 2015 - 9082907, in 2016. - 9113051, in 2017.9130197, in $2018-9137304$.

Table 5

Distribution of households by housing developed in different years

\begin{tabular}{|c|c|c|c|}
\hline Years & All households & Urban & Rural \\
\hline before 1950 & 7,3 & 6,2 & 9,5 \\
\hline In 1950s & 11,4 & 8,9 & 16,3 \\
\hline In 1960s & 21,7 & 19,8 & 25,7 \\
\hline In 1970s & 24,5 & 26,0 & 21,5 \\
\hline In 1980s & 24,5 & 27,5 & 18,2 \\
\hline In 1990s & 8,7 & 9,1 & 7,8 \\
\hline after 2000 & 2,3 & 2,4 & 2,2 \\
\hline
\end{tabular}

Source: ${ }^{15}$.

The total mass of the housing stock has aged, and its significant portion has reached the limit of its service life or the term of conducting major repairs and reconstructions.

Thus, the pre-war and post-war housing development built before 1980 $(81.8 \%)$ has reached the standard age to undergo major repairs, which, however, in the light of constant financial problems faced by Ukraine, have not been performed. It is easy to see that not less than $80 \%$ of houses need renovation of some kind or another.

On the other hand, the percentage of the households suffering the excessive degree of wear of their houses reached $64.9 \%$.

To conclude, the downfall of the volumes of housing construction, the onset of the critical age for most of the available housing stock and the low quality of premises have created a serious problem for the sustainable provision of housing for the citizens of Ukraine.

\section{Qualitative analysis of provision of housing to citizens}

Despite the average quantitative definitiveness of the housing stock, an issue emerges to do with the analysis of the quality of available homes and availability of living space in the context of constitutional provisions, public housing policy and the modern meaning of the notion of housing.

According to Article 379 of the Civil Code of Ukraine, housing of a physical person shall be a multi-apartment house, a flat or other premises intended and suitable for permanent residence. Thus, the notion of housing in the civil law encompasses two levels of objects: constructions (multi-

\footnotetext{
${ }^{15}$ Children, women and family in Ukraine. Statistical compilation. State Statistics Service of Ukraine. Kyiv. 2018. - 320 p. (in Ukrainian)
} 
apartment residential houses, manors, cottages, summer houses) and flats designed for long-term service and intended for being dwelled in ${ }^{16}$.

The Civil Code of Ukraine does not directly limit the norm of dwelling or total space per one person, therefore, according to the law, citizen can be co-owners and dwellers of premises with an area smaller than the one provided statutorily. The same applies to landlords, and this situation cannot be deemed acceptable.

Thus, the Housing Code of the Ukrainian $\mathrm{SSR}^{17}$ entrenched a provision on the prohibition of providing housing for two or more families or two or more single individuals in a flat intended for one family, which sometimes take place in practice.

In contrast to the lawmaker, the scientists understand housing not only as constructions, but also as adjacent territory, and not only the premises where people will immediately live, i.e., rooms, but also kitchen, corridor, bathroom, hallway, closets etc. ${ }^{21}$. Thus, in practice we deal with a multilevel, expanded notion of housing which is featured in the Constitution, which requires a comprehensive study and evaluation of its quality.

Scientifically grounded qualitative criteria and standards of housing found in regulatory documents change over time towards technical improvement (safety, energy efficiency, ecological safety) and comfort (availability of amenities). Besides, housing should be viewed not merely as premises fit for permanent or temporary habitation in a completed building, meeting the necessary health and safety and technical regulations, but also as real estate regarded as such as prescribed by the law, which is lawfully owned or used by a certain individual ${ }^{18}$.

Therefore, we believe that the necessary and sufficient criterion for the use of this notion is the concurrent availability of all the mentioned features or the conformity with all the listed criteria.

Consequently, the following houses cannot be considered as housing:

- ones which have been built and are used out of accordance with technical regulations;

- ones which do not meet health and safety norms, are situated in an unsafe and insalubrious environment;

${ }^{16}$ Civil Code of Ukraine: Scientific and Practical Commentary / under general editorship of Ye.O. Kharytonov, O.I. Kharytonova, N.Yu. Holubieva. - Kyiv: All-Ukrainian Editors' Association "Legal Entity", 2008. - 740 p.

17 Housing Code of the Ukrainian SSR [electronic resource]. - Access mode: https://zakon.rada.gov.ua/laws/show/5464-10.

${ }^{18}$ Yu.S. Lepekh. Right to housing as an object of administrative and legal regulation / Yu.S. Lepekh // Scientific newsletter of Lviv State University of Internal Affairs. - 2012. No. 3 - P. 244-251. http://www2.lvduvs.edu.ua/documents_pdf/visnyky/nvsy/ 03_2012/ 12lyusapr.pdf. 
- ones in which flats do not meet the regulations on provision of living space to their tenants;

- have not been accepted for operation and are mismanaged.

A matter worth to be mentioned separately is the acceptance of houses and flats into operation without the provision of amenities, which contradicts the essence of the concept of housing operation as its readiness to be used as intended. That is to say, in this case we cannot deem the respective citizens' constitutional right respective to housing to be properly exercised ${ }^{19}$. Flats' unreadiness distorts their value (price), which, as per expert assessment, increases by 20 to $30 \%$ due to their subsequent improvement, which has to be reflected in statistics.

Therefore, the state (local authorities) has to regulate the mandatory monitoring and control of the state of residential houses and premises for their conformity with the set of criteria allowing them to be deemed as housing and take measures to ensure such compliance.

On the other hand, we have to reconsider the complex and imperfect system of housing quality evaluation and control. The notion of the quality of a construction object includes its compliance with certain regulatory requirements at the moment of commissioning, as well as preserving this (or other regulatory) compliance throughout its whole operational phase already as a real estate item. While at the first stage quality control has to be ensured by a system of planning and design, construction appraisal and surveillance, subsequently in practice such control and surveillance became significantly weaker without being properly regulated.

As per the State Classifier of Buildings and Constructions, multiapartment buildings are houses having three and more flats, which are divided into three subclasses: multi-apartment buildings of mass development, individual high-comfort multi-apartment buildings, and hoteltype residential houses ${ }^{20}$. More precise characteristics of such houses are provided in the State Construction Regulations (SCR).

Thus, SCR B.2.2-15-2005 "Houses and Constructions. Dwelling Houses. Fundamental Provisions" 21 regulates the quality of flat planning, the flat space and the height of the ceilings (table 6).

${ }^{19}$ Yu.S. Lepekh. Right to housing as an object of administrative and legal regulation / Yu.S. Lepekh // Scientific newsletter of Lviv State University of Internal Affairs. - 2012. No. 3 - P. 244-251. http://www2.lvduvs.edu.ua/documents_pdf/visnyky/nvsy/ 03_2012/ 12lyusapr.pdf.

${ }^{20}$ State Classifier of Buildings and Constructions SC 018-2000 [electronic resource]. Access mode: https://zakon.rada.gov.ua/rada/show/va507565-00/.

${ }_{21}$ State Construction Regulation B.2.2-15-2005 Houses and Constructions. Dwelling Houses. Fundamental provisions [electronic resource]. - Access mode: https://zakon.rada.gov.ua/rada/show/v0175667-05/sp:wide/ 
Characteristics of flat in houses

\begin{tabular}{|c|c|c|c|c|c|}
\hline & \multicolumn{5}{|c|}{ Number of rooms } \\
\cline { 2 - 6 } & $\mathbf{1}$ & $\mathbf{2}$ & $\mathbf{3}$ & $\mathbf{4}$ & $\mathbf{5}$ \\
\hline Higher and lower limit of space, $\mathrm{m}^{2}$ & $30-40$ & $48-58$ & $60-70$ & $74-85$ & $92-98$ \\
\hline
\end{tabular}

Source: ${ }^{8}$

The mentioned document does not provide for the class of unusable housing; however, in practice such houses and premises, i.e. those, which do not meet regulatory requirements, exist.

The main document regulating the compliance with performance specification (regarding maintenance, routine and major repairs and reconstruction) is the Rules for Maintaining Residential Houses and Adjacent Territories ${ }^{22}$.

Analyzing the document, we can identify the main characteristics of residential houses to undergo qualitative analysis: the construction and state of ground work, walls and flooring, roofs, facades; thermotechnical characteristics of protection structures; equipment, construction and state of installations and lifts; size of the adjacent territory, amount and type of planted land; availability of fire safety systems; availability of a utility metering system; availability of special service equipment (video surveillance, security system etc.). For each structural element of a building or utility equipment part, a period of efficient service is determined; however, no such period is provided for management practice. Most performance indicators, which are not sufficient for operating management, are reflected in the technical passport of the house stored at the major-domo. As a rule, no other necessary documentation is available.

Residential premises' inhabitability, or the appropriateness of classifying premises as residential has to be determined by routine inspection of residential houses, which has to be conducted on the basis of the Provision on the procedure of inspecting the state of residential houses to estimate their compliance with sanitary and technical requirements and recognizing residential houses and residential premises uninhabitable ${ }^{23}$. In practice such

\footnotetext{
${ }^{22}$ Rules for Maintaining Residential Houses and Adjacent Territories. Order of the State Committee of Ukraine for Housing and Utility Services No.76 dated 17 May 2005 [electronic resource]. - Access mode: https://zakon.rada.gov.ua/laws/show/z0927-05.

${ }^{23}$ Provision on the procedure of inspecting the state of residential houses to estimate their compliance with sanitary and technical requirements and recognizing residential houses and residential premises uninhabitable approved by the Decree of the Council of Ministers of the Ukrainian SSR dated 26 April 1984 No.189 [electronic resource]. - Access mode: https://zakon.rada.gov.ua/laws/show/189-84-ח.
} 
inspections are not conducted systematically, which distorts the statistical data on the state of houses.

The peculiarity of forming the domestic standard housing stock contributed to the emergence of such group feature of a house as development type characterizing houses by a combination of indicators: development year, construction technology (panel, pre-engineered, brick houses), architectural features, proportion of such houses in the housing stock. The development type determines the largest groups of houses in the housing stock of big cities and can be used to qualitatively characterize them. Development type-based management facilitates the solution of the problems connected with maintenance and repairs of the houses.

The represented data lead to the conclusion that houses utilized by most citizens were built before the current norms have been introduced, do not comply with modern quality requirements and need major repairs, modernization or reconstruction. This is corroborated by statistical data on the improvement (equipment) of flats in houses provided in Table 7.

Table 7

Equipment of housing

\begin{tabular}{|c|c|c|c|c|c|}
\hline \multirow{2}{*}{ Years } & \multicolumn{5}{|c|}{ Share of the total area equipped with } \\
\cline { 2 - 6 } & water supply & sewage & $\begin{array}{c}\text { central } \\
\text { heating }\end{array}$ & gas supply & hot water supply \\
\hline 1995 & 50.5 & 47.3 & 47.9 & 79.9 & 35.0 \\
\hline 2000 & 54.2 & 51.4 & 52.8 & 81.9 & 38.6 \\
\hline 2005 & 56.2 & 53.8 & 56.2 & 82.6 & 40.0 \\
\hline 2010 & 59.6 & 57.5 & 62.1 & 83.2 & 43.1 \\
\hline 2015 & 60.8 & 58.8 & 68.7 & 83.3 & 47.0 \\
\hline 2016 & 61.2 & 59.2 & 68.9 & 83.1 & 47.0 \\
\hline 2017 & 61.8 & 59.8 & 69.1 & 83.1 & 47.5 \\
\hline
\end{tabular}

Source: State Statistics Service of Ukraine

The table demonstrates that a large proportion of dwellings does not meet the modern requirements to quality housing. This means that facilitation of bringing the quality of housing of all citizens in line with regulatory requirements should be a major endeavor.

It is also necessary to ensure the compliance with sanitary and hygienic regulations, which includes a wide range of requirements as to insolation, natural illumination, ventilation, ionization, microclimate and noise protection of premises in residential houses, set forth by sanitary and hygienic regulations, state standards, rules of urban and rural planning and 
development, in particular by the ones approved by the Order of the Ministry of Health of Ukraine ${ }^{24}$.

Further, according to the Law of Ukraine "On the Fundamentals of Social Protection of the Homeless Citizens and Gutter Children" it is believed that homeless people include individuals living in unfinished buildings, other premises undesignated or unsuitable for living, including residential premises in the state of disrepair ${ }^{25}$.

The latest statistical data for 2014 indicated that the number of residential facilities under construction reached 3,823. The situation with the flats and houses which have not been accepted into service but have been occupied is also complicated, as their monitoring and surveillance on the local level is necessary (earlier we have discussed the non-correspondence of shell-andcore flats accepted into service to the notion of housing). Similarly, the dates and the fact of acceptance of a construction object into service and property rights registration also require comprehensive control.

The monitoring of the housing stock state in dynamics also need to be improved substantially. The methodology of displaying the state and qualitative dynamics of housing stock is questionable: it indicates a relative stability of the spaces of old and failing housing stock along with a drastic fall of its de-commissioning, especially considering the low rates of houses rejuvenation. The objects and spaces of such houses should be clarified and confirmed, and the regulatory requirements for inspection of such houses should be implemented.

The above documents, however, do not regulate the conditions of occupation of flats of different forms of property, when even a quality housing in a quality house and environment loses its quality when overpopulated. Resettlement of citizens in various premises is very diverse (table 8 ).

Table 8

Irregularity in resettlement of citizens in premises of various area

\begin{tabular}{|c|c|c|c|}
\hline \multirow{2}{*}{$\begin{array}{c}\text { Living space area per one } \\
\text { individual, } \mathbf{~ m}^{\mathbf{2}}\end{array}$} & \multicolumn{3}{|c|}{ Share of individuals provided with living space, \% } \\
\cline { 2 - 4 } & countrywide & in urban settlements & in rural areas \\
\hline below 7.5 & 9.1 & 11.1 & 5.2 \\
\hline $7.5-9.0$ & 5.0 & 5.4 & 3.9 \\
\hline $9.01-13.65$ & 24.7 & 26.4 & 21.2 \\
\hline above 13.65 & 61.2 & 57.1 & 69.7 \\
\hline
\end{tabular}

Source: ${ }^{27}$.

${ }^{24}$ Order of the Ministry of Health of Ukraine dated 19 June 1996 No.173 "On the Approval of State Sanitary Rules for Settlement Planning and Development” [electronic resource]. Access mode: https://zakon.rada.gov.ua/laws/show/z0379-96.

${ }^{25}$ The Law of Ukraine "On the Fundamentals of Social Protection of the Homeless Citizens and Gutter Children" dated 02 June 2005 No. 2623-IV [electronic resource]. - Access mode: https://zakon.rada.gov.ua/laws/show/2623-15. 
The table shows that $38.8 \%$ of individuals are not provided with even the statutory living space of $13.65 \mathrm{~m}^{2}$. There is a differentiation in the ratio between the number of rooms and members of a household. As much as $63.8 \%$ of one-room flats are inhabited by two or more persons, $42.9 \%$ of two-room flats are inhabited by three and more persons, $24.1 \%$ three-room flats are inhabited by four and more persons. At the same time, a significant proportion of individuals live in flats where the number of rooms exceeds the number of household members. For example, only one person lives in $17.3 \%$ of three-room flats; one or two persons live in $43.8 \%$ of flats with four or more rooms.

Besides, several historically shaped norms of housing provision are in use in Ukraine, which, in our opinion, do not have sufficient scientific justification and need to be reviewed and generalized.

As per the provisions of the effective Housing Code of the Ukrainian $\mathrm{SSR}^{17}$ on the provision of flats for citizens' use by the state and the "Rules of Keeping the Inventory of Citizens Requiring Improvement of Living Conditions and Provision of Dwelling Premises to Them in the Ukrainian SSR" ${ }^{26}$, the following limits were defined: not more than $13.65 \mathrm{~m}^{2}$ of living space per one person, but not less than the average level of living space securing in the given settlement. The Law of Ukraine "On Privatization of State Housing Fund" ${ }^{27}$ defines that the norms are $21 \mathrm{~m}^{2}$ of the total space per one individual plus additional $10 \mathrm{~m}^{2}$ per family.

As for social housing, the Cabinet of Ministers of Ukraine by its Resolution No. 219 dated 19.03.2008 "On Setting Provisional Standards for Provision with Social Housing" has established that the norm for citizens residing in social dormitories is $6 \mathrm{~m}^{2}$ per one person, in flats and one-flat houses this norm is $22 \mathrm{~m}^{2}$ of a total area per family of two and additionally $9.3 \mathrm{~m}^{2}$ per each next family member ${ }^{28}$. On this ground, local selfgovernment bodies could develop their norms in view of specific conditions. However, as it's known, the development of social housing was not widely adopted.

Instead, according to the ongoing affordable housing program, state support in providing citizens with their own housing started to be provided

${ }^{26}$ Decree of the Council of Ministers of the Ukrainian SSR and Ukrainian Trade Union dated 11 December 1984 No.470 "On Approval of the Rules of Keeping the Inventory of Citizens Requiring Improvement of Living Conditions and Provision of Dwelling Premises to Them in the Ukrainian SSR" [electronic resource]. - Access mode: https://zakon.rada.gov.ua/ laws/show/470-84-ח.

${ }^{27}$ The Law of Ukraine "On Privatization of State Housing Fund" [electronic resource]. Access mode: https://zakon.rada.gov.ua/laws/show/2482-12.

${ }^{28}$ Resolution of the Cabinet of Ministers of Ukraine dated 19.03.2008 No. 219 "On Setting Provisional Standards for Provision with Social Housing" [electronic resource]. - Access mode: https://zakon.rada.gov.ua/laws/show/219-2008-п. 
in limited amounts at the rate of not more than $21 \mathrm{~m}^{2}$ of total housing area per one person plus $10.5 \mathrm{~m}^{2}$ per family additionally ${ }^{29}$. In such a case, claimants had to own not more than $13.65 \mathrm{~m}^{2}$ of housing space. A total of 3,771 flats were provided in the period from 2010 to 2017.

Thus, monitoring and surveillance of citizens' provision with housing requires the due consideration of a number of criteria and limitations as to the quality of housing. The main groups of such criteria and limitations are concerned with the environment, house, flat and density of occupation. Considering the non-compliance to the regulations, the quality housing stock and citizens' provision with housing will have lower quantitative characteristics in terms of the housing space.

\section{CONCLUSTIONS}

1. The current situation with the housing stock state and spending power of the majority of population of Ukraine testifies, on the one hand, the necessity to re-orientate toward s the strategy of rebuilding and renewal of the available housing stock, and on the other hand - the necessity to strengthen the state's role in this process. To work out specific strategies for financial sources and legal mechanisms and considering the scale of the problem, we have to evaluate the capacities of separate groups of flat owners, condominium associations, as well as communities, state, and private investors to maintain, use and renew residential property.

2. When renewing housing stock, attention should be paid to the improvement of its quality. Ukrainian legislation lacks a single procedure to recognize premises as inhabitable, as well as the requirements to be met by residential property. Similarly, there is no single procedure for the necessary control and recognition of residential premises as uninhabitable. Accordingly, no reliable data on the inappropriate state of houses and adjacent territories are available, in particular, for different settlements and houses of all forms of ownership. This artificially overrates the average statistic level of citizen's provision with housing.

3. The article demonstrates that a significant proportion of living spaces apparently cannot be considered residential premises. Thus, the state housing policy has to task itself with bringing the residential spaces used by individuals in compliance with current requirements to the quality of residential property. It is expedient to introduce a single norm to regulate the minimum of quality residential area per one person, which would be taken into account both in designing and construction, and registering for the

\footnotetext{
${ }^{29}$ Resolution of the Cabinet of Ministers of Ukraine dated 11.02.2009 No. 140 "Procedure of State Support to Provide Citizens with Affordable Housing". https://zakon.rada.gov.ua/laws/ show/140-2009-ח
} 
entitlement to receive a flat from the state, assistance in purchasing affordable housing, as well as in planning measures of state support for improving housing quality. The limits for such minimum should not be prescriptive but should rather be determined through calculations and consideration of households' capability to properly maintain such housing, including its repairs.

\section{SUMMARY}

The paper analyzes the strategies and results of housing policy in Ukraine in terms of construction and maintenance of buildings and housing provision to citizens in accordance with the Constitution.

The whole housing stock in Ukraine is now practically private. In the 1990s most of the flats in the multi-apartment buildings have been privatized by the tenants free of charge. Social housing stock is almost absent. The new construction is decreasing. The share of public financing in housing construction is less than 1 per cent. About $80 \%$ of all buildings in the cities have been built earlier than 1980, are not yet repaired and require urgent modernization with the cost equal to the actual State budget revenue. By the law of 2015, the responsibility for carrying out capital repairs has been transferred to the tenants who are co-owners of the buildings. The tariff for housing services does not include the component of capital repairs. Houses in the worst condition are inhabited by the poorest families which have no means to maintain and repair their houses because one half of all families in the country receive subsidies to pay their utility bills. However, in most countries, residential subsidies do not apply to real estate owners.

In conditions of low citizen's solvency there is a direct relationship between the level of state presence in the residential sector and the improvement of housing provision. At the same time, the necessity of rational attraction of solvent citizens to housing construction and maintenance is obvious. Taking into account other urgent and costly needs to maintain public infrastructure, the State is also unable to accumulate sufficient funds to renovate the housing stock. At the same time, there is the issue of the justice of additional state assistance to homeowners for repairing their assets at the expense of all taxpayers. Another question is how to operate this private property on the market.

In addition to the quantitative goals of citizen's housing provision, the quality of houses and flats must be analyzed. The approach to determining the notion of "housing" based solely on the characteristics of the living area of the houses without quality analysis and actual use is insufficient to assess the level of citizen's housing provision. The data shows that the houses of the majority of citizens do not meet the modern quality requirements and require not only capital repair but modernization or reconstruction. Also, the 
resettlement of citizens in dwellings is characterized by considerable differentiation and should be monitored. The standards of living space provision should also be resettled.

Thus, the main housing sector problem is the possible mismatch between the housing need as a vital necessity and the lack of opportunities for its satisfaction by an individual, social group or society, which requires state regulation and redistribution of necessary resources.

The following problems require analysis and solution at the national and local levels: assessment of the housing stock and calculation of accumulated needs for its renewal, the full cost of housing ownership and household's solvency in terms of self-financing, formulation of an appropriate strategy of public policy in the housing sector and its realization instruments.

Ukrainian Governments that frequently replace each other are afraid to raise this problem, which requires extraordinary decisions. It becomes obvious that homeowners are mostly inefficient, but the idea of reprivatization can cause social rejection. There are no analogues in the history or in other post-Soviet countries, where either the condition of privatized houses was better, or household incomes were higher, or state aid was regular and where, due to the tariff, funds for capital repairs have always been accumulated and used.

\section{REFERENCES}

1. Constitution of Ukraine. // URL: http://www.president.gov.ua/ documents/constitution.

2. V.Yu. Bozhanova. Business mechanism of increasing housing availability for population. Dnepropetrovsk. Science and Education, 2007. 392 p. (in Ukrainian)

3. D.L. Levchynskyi. Government regulation of the investment process of housing stock reconstruction : synopsis of a thesis for the degree of Doctor of Economics : 08.00.03, Zaporizhzhia, Classical Private University. 2012. 40 p. (in Ukrainian)

4. I.V. Lysov. State housing policy of Ukraine and its regions: theory, methodology, practice [Text] : monograph / I.V. Lysov, Academy of Municipal Administration - Donetsk : Iuho-Vostok Publishing House, 2012. - 399 p. (in Ukrainian)

5. Yu.M. Mantsevych. Social and economic issues of the development of housing services in Ukraine and the strategy of its improvement: [monograph]. Kyiv. Profi-Inform Publishing House. 2007. - 388 p. (in Ukrainian)

6. O.M. Nepomniashchii. Methodological framework for forming and implementing state housing policy : synopsis of a thesis for the degree of 
Doctor of Sciences in State Administration : 25.00.02. Donetsk. Donetsk State University of Management. 2013. - 36 p. (in Ukrainian)

7. N.I. Oliinyk, State regulation of the housing market in Ukraine. Thesis for the degree of Doctor of Sciences in State Administration, 25.00.02. Kyiv, National Academy of State Administration. 2011. - 391 p. (in Ukrainian)

8. V.A. Omelchuk. State regulation of the affordable housing market in Ukraine. Thesis for the degree of Doctor of Sciences in Economics 08.00.03. - Economics and National Economy Management. Kyiv. Scientific and Research Institute of Economy. 2012. - 422 p. (in Ukrainian)

9. K.V. Palyvoda. Monetary resources and financial mechanisms of capital investment into housing construction : synopsis of a thesis for the degree of Doctor of Sciences in Economics : 08.00.08. Kyiv. No publishing house. 2010. - 38 p. (in Ukrainian)

10. V.A. Kravchenko, K.V. Palyvoda V.A. Poliachenko. Fundamentals of housing economics. Kyiv. Osnova. 2007. - 416 p. (in Ukrainian)

11. T.V. Nikolaieva. Financial and economic mechanism of maintaining and reconstructing housing stock in the context of ownership relations transformation. Scientific bulletin of the National University of the State Tax Office of Ukraine (Economy, Law). I Science editor P.V. Melnik. Kyiv, National University of the State Tax Office of Ukraine. 2012. No. 1 (56). - P.81 - 85 (in Ukrainian)

12. P.O. Panteleiev. Investment process of maintaining residential houses. Forming market relations in Ukraine. 2013. No. 11 - P. 108-112 (in Ukrainian)

13. V.P. Nikolaiev, A.A. Shcherbina. A model of development of a residential property and housing and utilities services market in view of consumers' payment capacities. Construction operations : cross-sectoral scientific and technical collection of works. Kyiv. Research Institute of Building Production. 2017. No. 63/3 - P. 34-41 (in Ukrainian)

14. Housing stock of Ukraine in 2010. State Statistics Service of Ukraine. Kyiv. 2011. - 376 p. (in Ukrainian)

15. Children, women and family in Ukraine. Statistical compilation. State Statistics Service of Ukraine. Kyiv. 2018. - 320 p. (in Ukrainian)

16. Civil Code of Ukraine: Scientific and Practical Commentary / under general editorship of Ye.O. Kharytonov, O.I. Kharytonova, N.Yu. Holubieva. - Kyiv: All-Ukrainian Editors' Association "Legal Entity", 2008. - 740 p.

17. Housing Code of the Ukrainian SSR [electronic resource]. Access mode: https://zakon.rada.gov.ua/laws/show/5464-10.

18. Yu.S. Lepekh. Right to housing as an object of administrative and legal regulation / Yu.S. Lepekh // Scientific newsletter of Lviv State 
University of Internal Affairs. - 2012. - No. 3 - P. 244-251. http://www2.lvduvs.edu.ua/documents_pdf/visnyky/nvsy/03_2012/12lyusap r.pdf.

19. D.O. Kharchenko. State regulation of the enforcement of housing rights of citizens of Ukraine / D.O. Kharchenko, M.S. Kuibida. // Democratic Governance. - 2016. - Issue 16-17. [electronic resource]. Access mode: http://nbuv.gov.ua/UJRN/DeVr_2016_16-17_14.

20. State Classifier of Buildings and Constructions SC 018-2000 [electronic resource]. - Access mode: https://zakon.rada.gov.ua/rada/ show/va507565-00/.

21. State Construction Regulation B.2.2-15-2005 Houses and Constructions. Dwelling Houses. Fundamental provisions [electronic resource]. - Access mode: https://zakon.rada.gov.ua/rada/show/v017566705/sp:wide/.

22. Rules for Maintaining Residential Houses and Adjacent Territories. Order of the State Committee of Ukraine for Housing and Utility Services No. 76 dated 17 May 2005 [electronic resource]. - Access mode: https://zakon.rada.gov.ua/laws/show/z0927-05.

23. Provision on the procedure of inspecting the state of residential houses to estimate their compliance with sanitary and technical requirements and recognizing residential houses and residential premises uninhabitable approved by the Decree of the Council of Ministers of the Ukrainian SSR dated 26 April 1984 No.189 [electronic resource]. - Access mode: https://zakon.rada.gov.ua/laws/show/189-84-п.

24. Order of the Ministry of Health of Ukraine dated 19 June 1996 No.173 "On the Approval of State Sanitary Rules for Settlement Planning and Development" [electronic resource]. - Access mode: https://zakon.rada.gov.ua/laws/show/z0379-96.

25. The Law of Ukraine "On the Fundamentals of Social Protection of the Homeless Citizens and Gutter Children" dated 02 June 2005 No. 2623-IV [electronic resource]. - Access mode: https://zakon.rada.gov.ua/ laws/show/2623-15.

26. Decree of the Council of Ministers of the Ukrainian SSR and Ukrainian Trade Union dated 11 December 1984 No.470 “On Approval of the Rules of Keeping the Inventory of Citizens Requiring Improvement of Living Conditions and Provision of Dwelling Premises to Them in the Ukrainian SSR" [electronic resource]. - Access mode: https://zakon.rada.gov.ua/laws/show/470-84-ח.

27. The Law of Ukraine "On Privatization of State Housing Fund" [electronic resource]. - Access mode: https://zakon.rada.gov.ua/ laws/show/2482-12. 
28. Resolution of the Cabinet of Ministers of Ukraine dated 19.03.2008 No. 219 "On Setting Provisional Standards for Provision with Social Housing" [electronic resource]. - Access mode: https://zakon.rada.gov.ua/laws/show/219-2008-ח.

29. Resolution of the Cabinet of Ministers of Ukraine dated 11.02.2009 No. 140 "Procedure of State Support to Provide Citizens with Affordable Housing”. https://zakon.rada.gov.ua/laws/show/140-2009-ח

30. L.M. Bohoslovska. The notion of the constitutional right of a human and citizen to housing in Ukraine / L.M. Bohoslovska // Scientific newsletter of Dnipropetrovsk State University of Internal Affairs. - 2009. No. 1 - P. 55-63.

31. Children, women and family in Ukraine. Data as of November 2017. [electronic resource]. - Access mode: http://www.ukrstat.gov.ua/druk/ publicat/kat_u/2018/zb/09/DJS_2018_pdf.pdf.

\section{Information about the author: \\ Nikolaiev V.P.,}

Doctor of Economics, Professor,

National Academy of State Administration under the President of Ukraine 20, Antona Tsedika str., Kyiv, 03057, Ukraine 